\title{
Triangulation methods for effusion holes measurements in combustion chambers of aircraft engines
}

\author{
Triangulacyjne metody pomiarów otworów efuzyjnych \\ w komorach spalania silników lotniczych
}

\author{
PIOTR LAMPA \\ MARIUSZ MRZYGŁÓD \\ JACEK REINER*
}

An important problem of modern aero-engines' construction is effective cooling of combustor liner attained by effusion holes. The laser-drilled channels are a critical metrological challenge resulting from their small diameter (below $1 \mathrm{~mm}$ ), irregular shape and angular orientation to the surface. Hence, in this case, the tactile CMM measurement methods are timeconsuming, error-susceptible and hazardous to the measuring stylus. The paper compares two methods of triangulation scanning of the surface of the engine combustion chamber with angular effusion holes (according to normal to surface and coaxially with hole). Additionally, four algorithms for processing measurement data were developed and evaluated, aiming at determination of the position and holes diameter. The paper also discusses the problem of measurement and calculation disturbance.

KEYWORDS: effusion holes, laser triangulation, machine vision, optical measurement

Ważnym problemem dotyczącym konstrukcji nowoczesnych turboodrzutowych silników lotniczych jest efektywne chłodzenie komór spalania, realizowane poprzez otwory efuzyjne. Kanały takie, drążone laserowo, stanowia jednak poważne wyzwanie metrologiczne ze względu na niewielką średnicę (poniżej $1 \mathrm{~mm}$ ), nieregularny kształt i kątową orientację względem powierzchni. Pomiary metodami kontaktowymi CMM są więc czasochłonne, obarczone znaczną niepewnością pomiaru oraz ryzykiem uszkodzenia trzpienia pomiarowego. W artykule porównano dwie metody skanowania triangulacyjnego powierzchni komory spalania silnika z kątowymi otworami efuzyjnymi (w kierunku normalnym do powierzchni oraz współosiowo z otworem). Ponadto oceniono cztery opracowane algorytmy przetwarzania danych pomiarowych, których celem jest wyznaczenie położenia i średnicy otworów. Wskazano na problem zakłóceń dotyczących pomiaru i przetwarzania danych. SŁOWA KLUCZOWE: otwory efuzyjne, triangulacja laserowa, wizja maszynowa, pomiary optyczne

Efficiency and environmental performance of jet aircraft engines depends mainly on the temperature of the combustion [9]. For highest temperature of combustion, their elements are manufactured from monocrystalline materials, super-alloys or ceramic-metal composite structures. In addition, the thin air film is formed just off the walls of the internal thermal barriers. This film is obtained by forcing air through the effusion holes. For homogeneous distribution of the pressure, as possible without turbulence areas, axes of the holes shall be at an acute angle to the surface [10]. However, manufacturing and measuring such holes with diameters $0.5 \div 0.8 \mathrm{~mm}$ is a real technological chal-

\footnotetext{
* Mgr inż. Piotr Lampa (piotr.lampa@pwr.edu.pl), mgr inż. Mariusz Mrzygłód (mariusz.mrzyglod@pwr.edu.pl), dr hab. inż. Jacek Reiner (jacek.reiner@pwr.edu.pl) - Politechnika Wrocławska
}

\author{
DOI: https://doi.org/10.17814/mechanik.2017.12.199
}

lenge. Due to a high process performance, laser drilling is applicable for their manufacturing. During percussion drilling of angular holes, their shape significantly deviates from the cylindrical [4]. In addition, thin-walled combustion chambers with a thickness of $0.7 \div 1.0 \mathrm{~mm}$ are vulnerable to geometric deformation during processing, which, in the case of tool positioned at an acute angle $\left(20 \div 30^{\circ}\right.$ to the surface), results in significant displacement of the hole. Although the most important functional parameter of effusion holes is an airflow, the quality specification also includes their diameter and position [1]. The measurements by touch coordinate technique (on CMM) are very time-consuming and susceptible to damage of the touch probe tip with a diameter of $0.2 \div 0.3 \mathrm{~mm}[11,13]$. Thus, a thorough measurement of several hundred holes in one chamber is practically unrealizable. Attempts to apply optical scanners of general purpose have failed because of excessive uncertainty determination of diameter and position of geometrically distorted angular holes.

The paper presents results of applying a triangulation scanner and comparison of two scanning methods (in accordance with normal and coaxially to holes) of turbojet engine combustion chamber surface, as well as discussion and the assessment of the measurement data processing algorithms in order to identify diameter and position of angular effusion holes. The problem of measurement and calculation of disturbances has been discussed.

\section{Effusion holes}

Multi-pulse laser piercing is the most commonly used method of drilling effusion holes with diameters of $0.5 \div 0.8$ $\mathrm{mm}$. This technology is characterized by high efficiency $(1 \div 3$ holes per second) but does not provide their cylindricity. By performing metallographic cross-sectioning or computed tomography scanning with an image reconstruction, it is possible to observe the internal geometry of such holes (fig. 1).

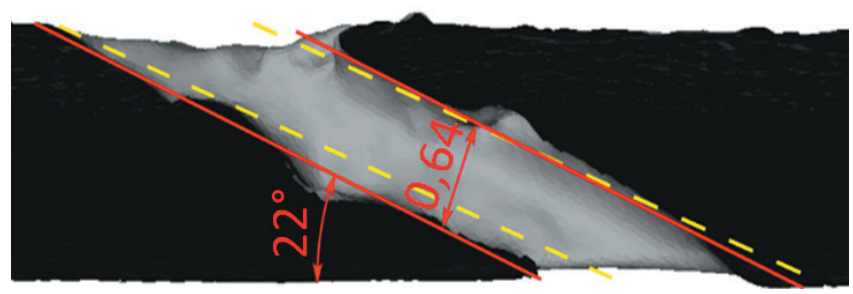

Fig. 1. Cross-section of the effusion hole - CT model

The cross-sectional image allows to observe the protrusions and depressions in the inner wall, which is the result of the impact of each high-energy pulse (1 to 3 ), i.e. melting and ejection of material and gases, vapors and liquid metal from weld pool and processing nozzle. 
The so-called calibration pulses $(4 \div 5)$ only partially minimize geometrical distortions. Furthermore, also the inlet and outlet edges of the hole are deformed. From the outlet, the effect of material eruption is observed, while from the inlet the effect of asymmetric melting of edges occurs, which is particularly large on a sharp side (fig.1).

Geometric quality specification of holes, besides the airflow, determines their diameter and position of the point of intersection of hole axis with a cylindrical surface of a nominal diameter of chamber, with an accuracy of hundreds millimeters.

As an experimental object the cylindrical tube with wall thickness of $0.8 \mathrm{~mm}$ was used, in which effusion holes of diameter $0.7 \mathrm{~mm}$ were drilled using laser. The drilling was performed at technological manufacturing stand in Pratt \& Whitney, Rzeszów, where the errors of shape and mounting of combustion chamber are automatically corrected.

The experimental object was installed on the rotary table XYC and the profilometer LJ-V7020 (Keyence) was used as a scan head (fig. 2), parameters of which are shown in table I.

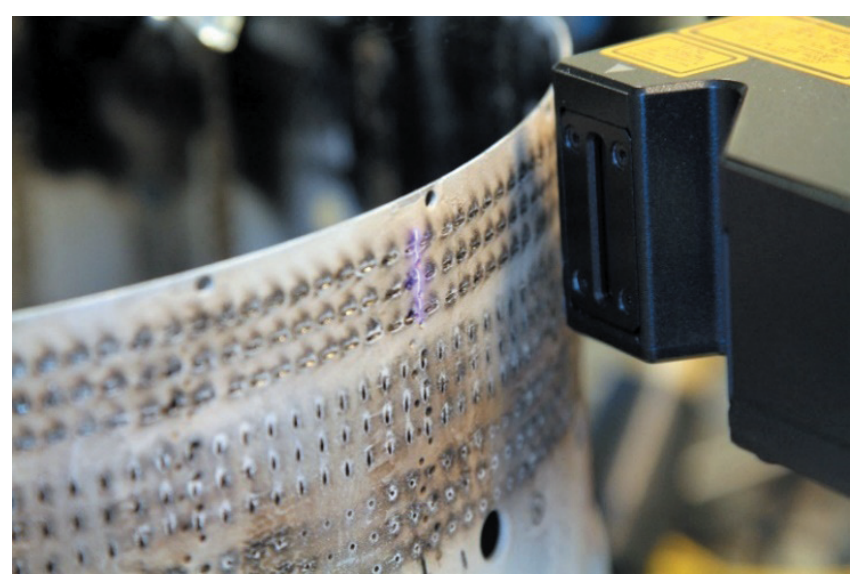

Fig. 2. Experimental setup with triangulation head

TABLE I. Laser profilometer characteristics

\begin{tabular}{|l|c|}
\hline \multicolumn{1}{|c|}{ Parameter } & Value \\
\hline Z-axis range (height), $\mathrm{mm}$ & $20 \pm 2.6$ \\
\hline Z-axis resolution, $\mu \mathrm{m}$ & 0.01 \\
\hline$Z$-axis repeatability, $\mu \mathrm{m}$ & 0.2 \\
\hline$X$-axis range (width), $\mathrm{mm}$ & 4 or 6 or 8 \\
\hline X-axis resolution, $\mathrm{mm}$ & 0.01 \\
\hline Maximum sampling, $\mu \mathrm{s}$ & 16 \\
\hline Trigger & continuous or external (e.g. encoder) \\
\hline
\end{tabular}

As a result of scanning with $4 \mathrm{~mm}$ profile, a range map was obtained, which then was processed on a 3D image with resolution of $400 \times 90000$ pixels. The $X$-axis of range map corresponds to the $Z$-axis of experimental object and the $Y$ axis corresponds to its rotary axis $C$. The map has 32 bit depth, however, only part of its range is used to encode the measured distances. Grayscale levels indicate proportionally the profile height, black pixels mean exceeding of the measuring range. Resolutions in $X$ and $Y$ of range map are different: $0.01 \mu \mathrm{m} /$ pixel and $0.017 \mu \mathrm{m} /$ pixel. The $Y$-axis resolution resulting from the motion and measurement systems is 0.004 degrees/profile, which gives resolution of $0.0086 \mathrm{~mm}$ at the outer diameter of the experimental object.

\section{Scan method}

The proposed scan method consists in measuring the distance between the sensor and external surface of the body. Point cloud, which corresponds to the model of topography with specified surface width, was obtained by rotating the measured chamber. In places of holes, where it is not possible to measure the distance, the minimum values occur (black). This means that the image segmentation is implemented by hardware without the need for describing the cut-off threshold.

Fig. 3. Two scanning principles: normal and axial orientation

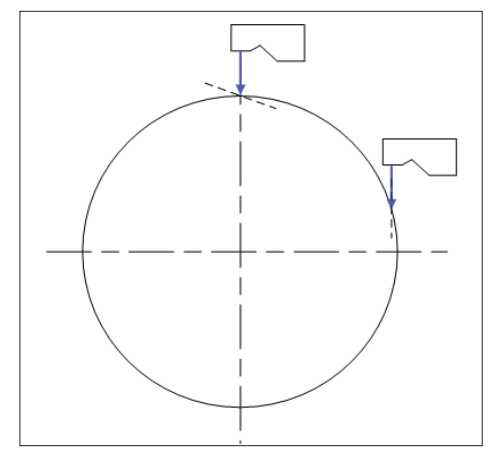

Because of the occlusion phenomenon characteristic for triangulation, by varying sensor angle setup (fig. 3), it is possible to scan different fragments of inner surfaces of effusion holes [14]. In both configurations, the socalled normal triangulation geometry is applied, i.e. when the axis of illuminator is directed perpendicularly to the scanned surface and the axis of camera is directed at an acute angle to the axis of illuminator [8].

In case when the axis of illuminator coincides with the perpendicular to the surface of chamber (fig. 4), partial representation of inner surface of angular hole is possible. The length of the scanned slope is dependent on the diameter of the hole and the angle of its axis.

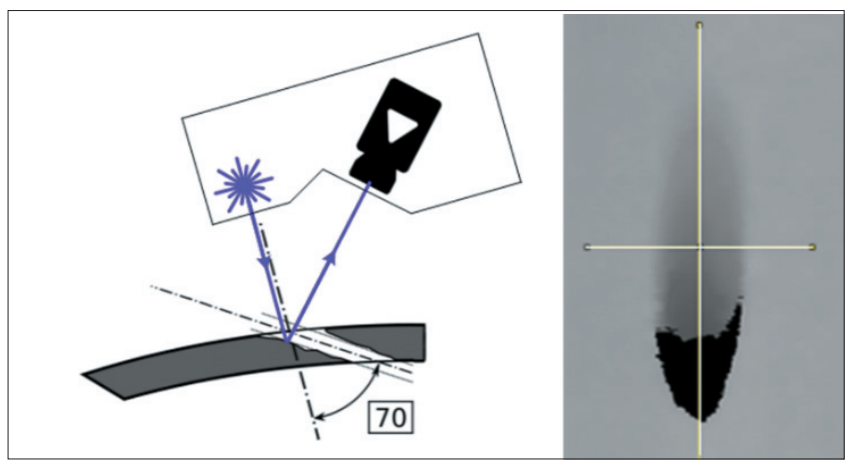

Fig. 4. Normal scanning principle with range map

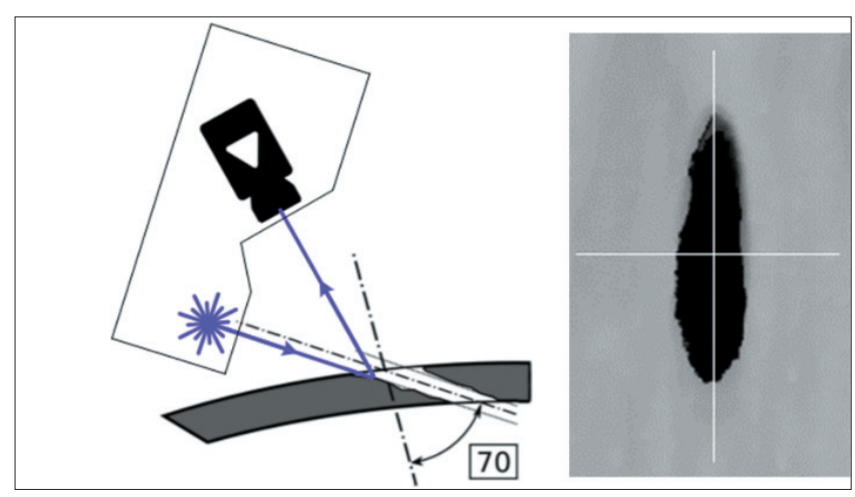

Fig. 5. Axial scanning principle with range map 
In case when the axis of illuminator is in-line with the axis of effusion hole (fig. 5), the inner surface of the hole is completely cut off from its surroundings. This cut off, however, is not on the edge of the surface.

Before the analysis of acquired imaging data, to their denoising and removal of edge artefacts, the morpho-logical closing operation with $3 \times 3$ kernel was being applied [12].

\section{Algorithms for determining the hole diameter}

Calculation of the diameter of holes requires definition of the geometric primitives being measured, hence there is the need to determine the edge points. Methods of determination of diameter based on ellipse fitting and measurements of width for both types of imaging, have been analyzed.

Although an ellipse is not result of intersection of two cylinders, in this case, an effusion hole and a combustion chamber, such approximation was considered satisfactory [2]. In case of the normal range map, area segmented is too small for the proper ellipse fit, hence the need for its enlargement.

As shown in fig. 6 , increasing threshold value increases the area of projection of the hole, which is accompanied by an increase in the value of minor axis of ellipse. However, even with the highest threshold cut-off value, the diameter of the hole estimated that way is less than the diameter measured using caliper function.

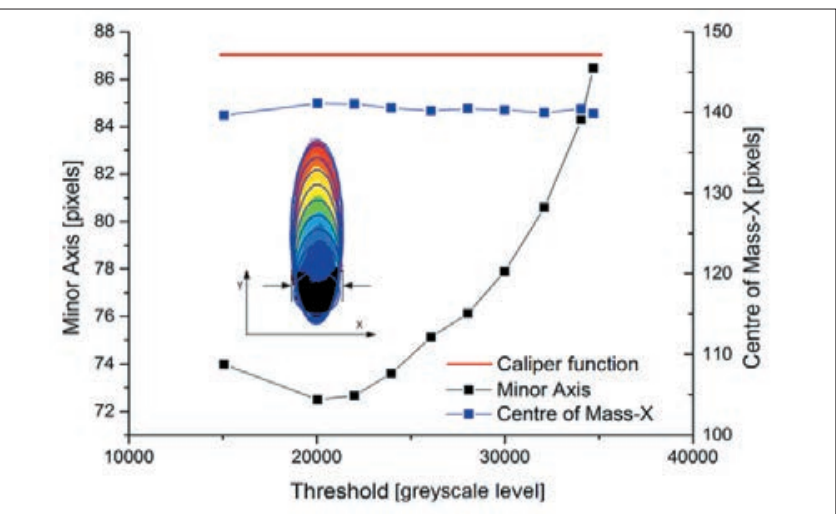

Fig. 6. Results of diameter measuring by ellipse fitting and caliper; results of $Z$-axis position measuring

In case of the axial range map, the entire surface of the hole projection is well separated. Ellipse fitting was performed on the set of edge points $[5,6]$. In both cases, the method of optimization of fitting was SVD [3].

It was noted that distance between the edges along the $X$-axis of the image are representative of the hole diameter. As shown in fig.1, edges along the $Y$-axis have been distorted by the partial melting or their location is not explicit. Thus, it was considered that a good estimator of the holes diameter, assuming no errors in their shape, would be the measurement of maximum width along the $X$-axis - the caliper function.

\section{Determining the position of hole in Z-axis}

The position of holes in Z-axis of chamber ( $X$-axis on the image) does not require the projection of hole axis position designated on the basis of range maps. As shown in fig. 6 (center of mass $-X$ ), regardless of the methods for determining the diameter and type of map, position in $Z$-axis is stable.

\section{Determining the position of hole in $C$-axis}

In case of axes of holes in the angular $C$ system, i.e. around the axis of rotation of the combustion chamber ( $Y$-axis on the image), it is necessary to project a designated center of the hole to the nominal diameter of combustion chamber. Two approaches have been analyzed: first, when the nominal value of angle of hole axis is adopted and second, when this angle is determined on the basis of measurements.

\section{Projection at the nominal angle of hole axis}

The idea of designation of center based on projection of the cross-section of hole is shown in fig. 7.

The method consists of the adoption of the nominal angle of hole and its diameter $d$ designated on the basis of measurements. With the known angle $\alpha$, the cut-off height $h$, which is the threshold level of range map, can be calculated. As a result of thresholding, the area is obtained (thick orange line) and its center is determined, which, simultaneously, is a center of a cross-section of hole (thick green line). Then, the center point is projected along the axis of hole (red dotted line) on the nominal diameter of combustion chamber (yellow line). The determined point is the $C$ axis coordinate that was searched for. The algorithm is then repeated for each hole.

The basis for this measurement is the edge of the hole, which, as have been discussed earlier, may be significantly eroded as a result of the drilling process. Therefore, this method for determining the position of the hole will be vulnerable to this type of disruptions.

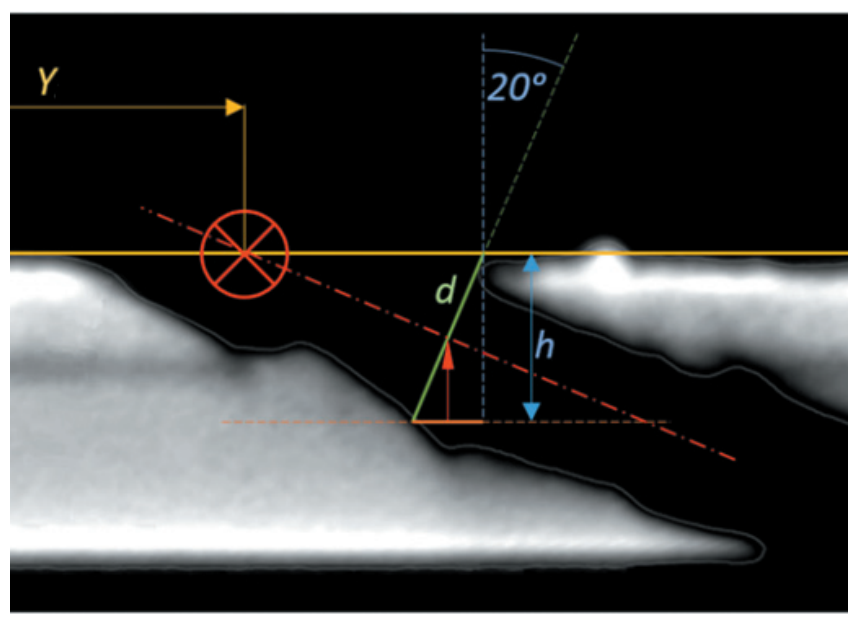

Fig. 7. Cross-section with projection of hole

\section{The slope of hole}

The opposite edge of the inlet is significantly less eroded, thus its adoption as a measuring base is reasonable. However, edge detection on the range map is difficult due to the lack of a clear range gradient.

This algorithm is based on designation of the actual slope of hole on the basis of the internal slope shown on the normal range map.

In the fig. 8, line I, which represents the slope of hole, is determined by linear regression of slope points using the robust statistics and Welsch $m$-estimator [7]. To improve the algorithm resistance to angular position errors of the holes, it is assumed that these points are minima in following cross-sections ( $X$ direction) through the slope (fig. 9 ). 


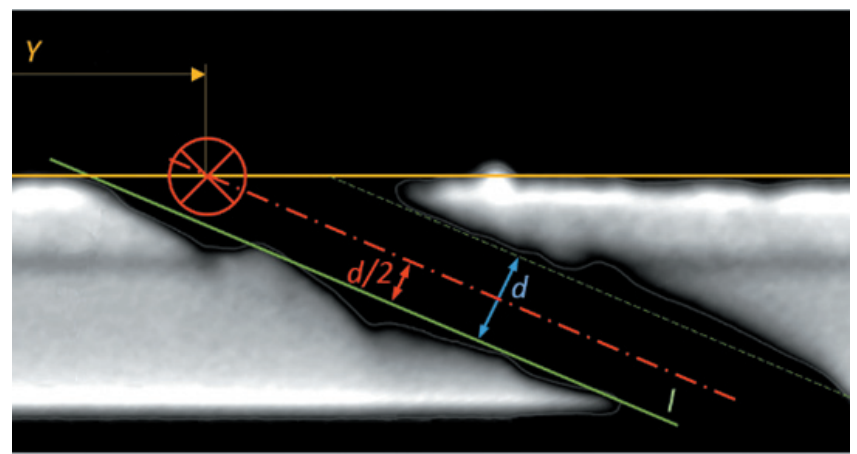

Fig. 8. Cross-section with slope reference line

Then the axis of hole is achieved by shifting the designated line I of half the length of diameter, measured by caliper function. The intersection of the axis found and the nominal diameter of chamber determines the position of hole in $C$ axis.

It should be noted that this method is vulnerable to angular disruptions of holes and their inner geometry.

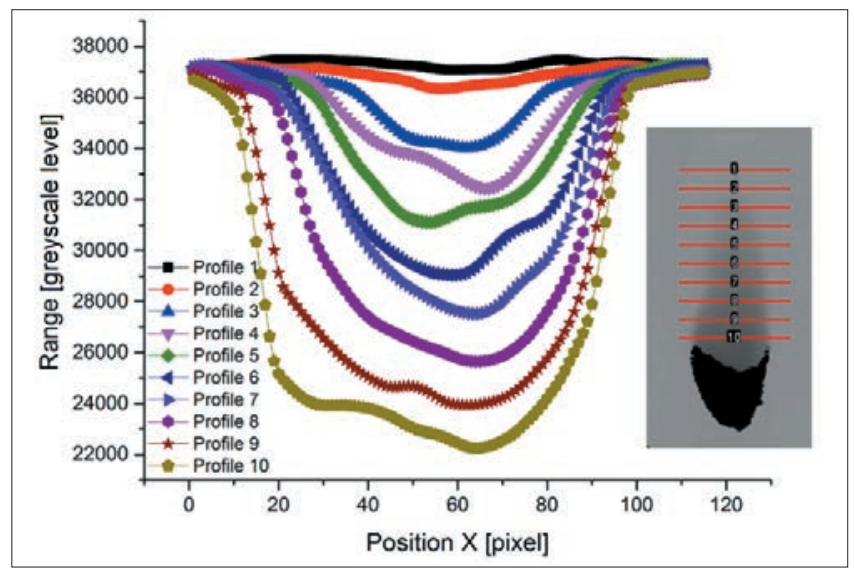

Fig. 9. Cross-section range profiles along the effusion hole

\section{Axial configuration}

Image obtained by coaxial acquisition method has the same format and scale as in the case of normal acquisition. Elongation of holes in image is larger due to different resolution in the $Y$ and $X$ axes and angle of observation.

In the axial case, locating hole is less complicated, because the edges are detected with high confidence. The comparison of results of the ellipse fitting algorithm and the algorithm for determining the center of mass based on the edge showed similarity. Both of these algorithms use hardware thresholding, which, in the case of axial configuration, moves the edge on the image deeper into the hole while minimizing the influence of erosion of the actual edge of hole.

\section{Experimental results}

There were performed scan series in normal and coaxial configurations. Then, obtained range maps were processed using developed algorithms to determine diameters and positions of holes. The obtained results have been referenced to the nominal values (compatible with CAD model). Therefore, presented characteristics contain realization errors (part variance) as well as method errors. However, such an analysis, without the measured reference values, allowed to preliminarily evaluate developed algorithms for processing measurement data.
Graphs of distributions of obtained diameter measurements (fig. 10) show that the results variance is the smallest when algorithms are based on the axial range map. In case of normal range map, the variance does not depend on used algorithm. Simultaneously, the result confirms the bias (underestimation) in the case of fitting ellipse algorithms, as shown in fig. 6 .

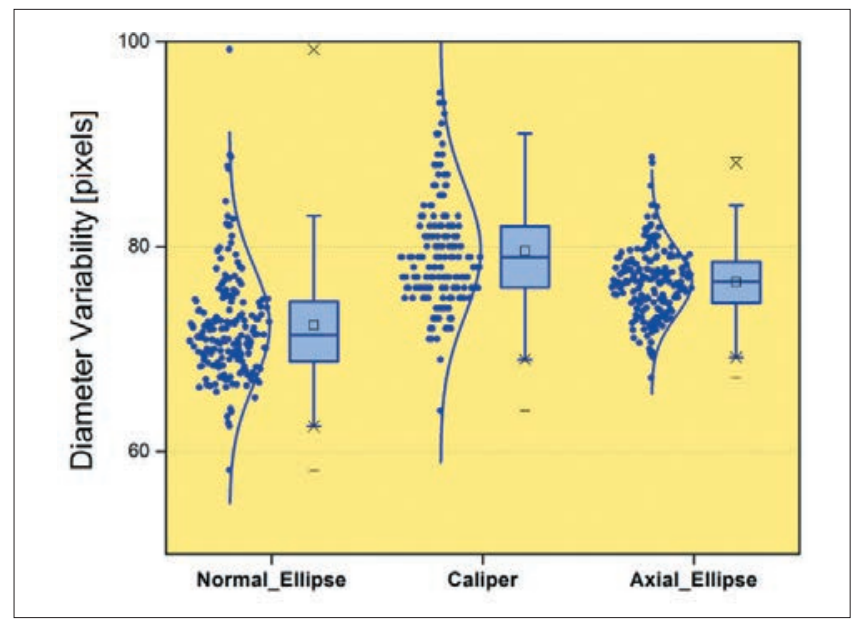

Fig. 10. Diameter variability as a function of algorithms

In case of determining the positions of holes, the smallest variance occurs with axial range map (fig. 11). In case of analysis of normal range map with the slope designation algorithm, bias is also noticeable. Distributions of variation are of different nature, which demonstrates that there were various disruptions in measurements.

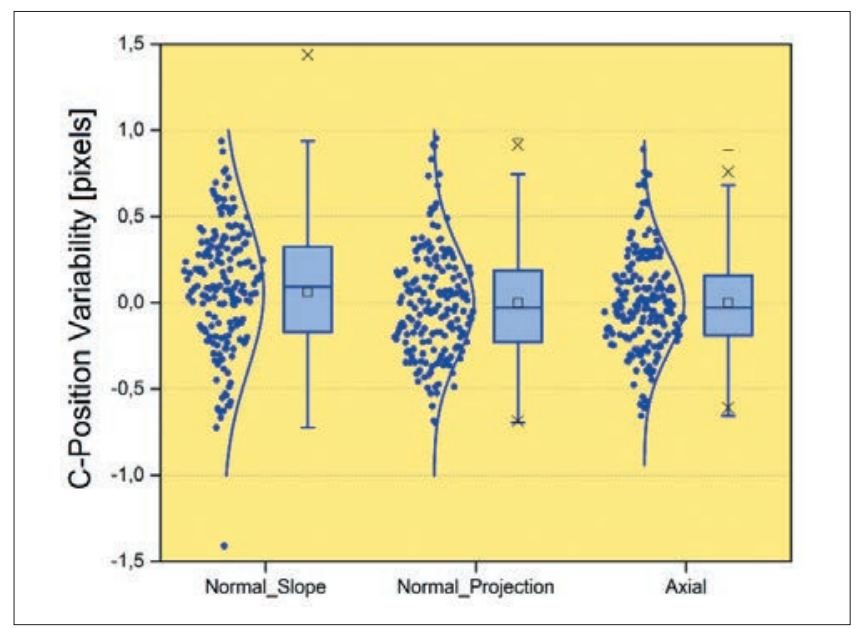

Fig. 11. C-axis position variability as a function of algorithms

\section{Conclusion}

The laser drilled effusion holes in thin-walled combustion chambers of aircraft engines have a significant divergence of geometrical features, including disruptions of shape. The application of optical methods to their measurements encounters problems with their imaging.

Scanning along a normal to the surface allows the acquisition of data on the leaning of slope of hole. However, acquired data represent the edge of inlet that is highly eroded on the side of an acute angle. Scanning along the axis of holes is the least burdened with disruptions and errors of imaging. In such configuration, the edge of hole is determined explicitly. In case of eroded edge, it is possible to record inner points of hole below the surface of inlet. 
However, in the angular configuration, the work distance of scanning head is drastically reduced, which can be the cause of collision. In addition, during angular scanning, on obtained range map, it is necessary to correct errors of shape and eccentricity of rotation of measured combustion chamber.

Studies have shown that in case of normal map, determination of diameter with ellipse fitting is underestimated. Much better results were provided with the measurement of maximum width (caliper function). However, the best results in the field of variance are obtained by the processing of data from the axial range map.

Determination of angular ( $C$ axis of chamber) positions of holes based on the normal range map is burdened with error of shape of inner surface, on the basis of which the slope of hole is determined, or with eroded edge of inlet. The determination based on axial map is free from these disadvantages. The results of the fig. 11 does not show clearly this difference, however, it should be noted that in the first two cases, number of degrees of freedom for calculations was reduced.

Further research will rely on differentiation of total variance to the share of data coming from the part variance and from measurement variance, with ANOVA methods. Also, there is being prepared a special part, which will be able to serve as a reference model measured by touch technique on CMM.

The research was conducted within the project InnoTech II INNOTECH-K2/IN2/46/182494/NRDC/13 ,Laser drilling technology for cooling holes in multilayer structures of modern turbine aircraft engines" with Pratt \& Whitney Rzeszów.

\section{REFERENCES}

1. Adamczak S. „Pomiary geometryczne powierzchni: zarysy kształtu, falistość i chropowatość". Warszawa: Wydawnictwa Naukowo-Techniczne, 2008

2. Ahn S. J., Rauh W., Warnecke H-J. „Least-squares orthogonal distances fitting of circle, sphere, ellipse, hyperbola, and parabola". Pattern Recognition. 34, 12 (2001): pp. 2283-2303.

3. Baker K. "The Singular Value Decomposition". The Ohio State University, 2005

4. Dhar S Saini N ., Purohit $R$. A review on laser drilling and its techniques". Fatehgarh Sahib: Proceedings of the International Conference of Advances in Mechanical Engineering, Baba Banda Singh Bahadur Engineering College, 2006: pp. 1-3.

5. Fitzgibbon A., Pilu M., Fisher R.B. „Direct least square fitting of ellipses". IEEE Transactions on Pattern Analysis and Machine Intelligence. 21, 5 (1999): pp. 476-480.

6. Gander W., Golub G.H., Strebel R. „Least-squares fitting of circles and ellipses". BIT Numerical Mathematics. 34, 4 (1994): pp. 558-578.

7. Genton M.G., Ma Y. „Robustness properties of dispersion estimators". Statistics \& Probability Letters. 44, 4 (1999): pp. 343-350.

8. Kowal J., Sioma A. „Metoda budowy obrazu 3D produktu z wykorzystaniem systemu wizyjnego". Acta Mechanica et Automatica. 4, 1 (2010): pp. 48-51.

9. Lefebvre A.H., Ballal D.R. „Gas turbine combustion: alternative fuels and emissions”. 3rd ed. Boca Raton: Taylor \& Francis, 2010.

10. Liu X., Zheng $\mathrm{H}$. „Influence of deflection hole angle on effusion cooling in a real combustion chamber condition". Thermal Science. 19, 2 (2015): pp. 645-656.

11. Ratajczyk, E. „Coordinate Measuring Technique”. Warsaw: Warsaw University of Technology Press, 2005.

12. Reiner J., Stankiewicz M. „Evaluation of the Predictive Segmentation Algorithm for the Laser Triangulation Method". Metrology and Measurement Systems. 18, 4 (2011): pp. 667-678.

13. Sładek J. "Coordinate Metrology Accuracy of Systems and Measurements". Berlin Heidelberg: Springer-Verlag, 2016.

14. Stankiewicz M. „Metoda triangulacji laserowej odporna na refleksy świetıne dla kontroli jakości geometrii wyrobu". Wrocław, 2013. 